\title{
GRADUATE OF RIGA POLYTECHNIC INSTITUTE, ENGINEER, INVENTOR AND ATHLETE ARNO LİCIS
}

\section{ËRIKA LANKA* \\ University of Latvia \\ ALİDA ZIGMUNDE}

Riga Technical University

\begin{abstract}
Summary. The article summarizes the career of a graduate of the Faculty of Mechanics (1964) of Riga Polytechnic Institute Arno Licis. The article reveals and describes his work while being an engineer at the Riga Electromachine Building Factory (RER), at the Latvian Scientific Research Institute of Traumatology and Orthopaedics (LSRITO) and in the printing house «Jāna sēta», as well as being an inventor. It has been discovered that he had promoted orienteering sports and had significant achievements in competitions of various scale, including mass competition named «Magnēts» managed by him, which had been taking place since 1969. This is the first research on the life and professional activities of engineer $A$. Licis, which is dedicated to his 80th birthday to be celebrated in July 2019. Data from the personal archive of $A$. Licis, documents of the Latvian State Historical Archives and the collection of the National Library of Latvia are collected in this article.
\end{abstract}

Keywords: Arno Līcis, graduates of RPI, orienteering sports, «Magnēts».

\section{Contribution of $A$. Lïcis to Orienteering Sports Through Mass Competition «Magnēts»}

The number of graduates of RPI amounts to many thousands and each of them has given his contribution and left some evidence behind for the future generations. Graduate of the Faculty of Mechanics of RPI Arno Licis is one of those whose name is inextricably linked to the life and events of RPI and the Republic of Latvia in the 20th and 21st centuries.

\footnotetext{
* Corresponding author.

E-mail: erikalanka@inbox.lv
} 
The authors of the article studied the areas of the life of graduate A. Licis where his contribution has been significant and will remain in future.

A. Lìcis is a well-known orienteerist in Latvia and plays an important role in the creation and organization of orienteering competition «Magnèts». In 2019, «Magnēts» is celebrating its 50th anniversary. Already during his studies in 1963, A. Licis became a board member of the Latvian Orienteering (at the beginning - tourist) Federation. His name is on the list until 1973. From 1963 to 1983, A. Licis also headed the orienteering sports section of the Sports Association «Daugava».

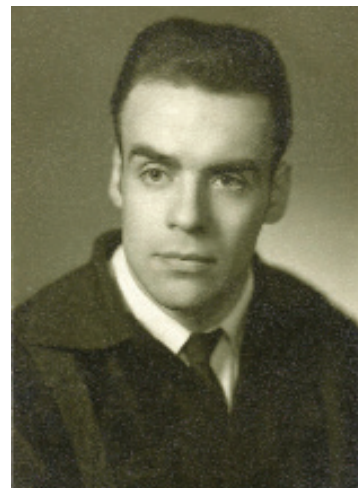

Figure 1. $A$. Licis at the beginning of the 1960s [1].

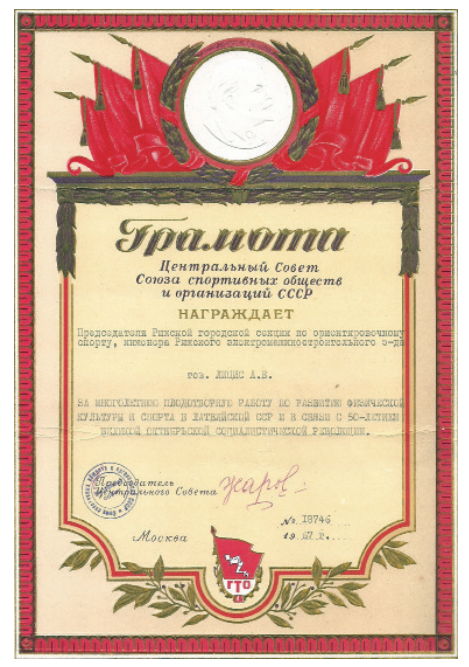

Figure 2. Honorary Award of the Central Council of the Union of Sports Associations and Organizations of the Union of Soviet Socialist Republics (USSR) to A. Licis (1967) [2].

The rank of Master of Sports in Latvian Orienteering Sport were introduced in 1966. A. Licis became a master of sports of the USSR in orienteering in 1967 and his future wife Ievina Lice - a year later, in 1968.

In the autumn of 1968, A. Licis with a USSR Tourist Group left for Sweden to observe the World Orienteering Championship. There were four people in the group from Latvia. The USSR was not yet a member of the International Federation therefore the group did not start at the official start, but took part in the races of World Championship.

The Latvian Orienteering Federation instructed $A$. Licis to create a form of competition for working people and athletes in the evenings of working days, which would be suitable for different age grups of different mastery level. After summing up everything that has already been created in the world, as well as learning from the mass participation of the Swedish orienteerists, A. Licis proposed and organized the orienteering competition «Magnēts-69» [3], which was scheduled for 10 Wednesday evenings from 4.00 p.m. to 7.00 p.m. Participants could choose a distance appropriate for their skills and age. Rodrigo Slaviňš, the first 
President of the Latvian Orienteering Federation, in the autumn of 1969, gathered representatives from all Latvian tourist clubs and A. Licis introduced them to the results of the first year of «Magnèts» and made suggestions on how to improve the process of such competitions. In the competitions before «Magnèts», about hundred men and hundred women took part, later - after introducing «Magnèts» - it turned into the first Latvian mass orienteering competition.

In the following years, similar competitions took place in about 20 centres. In 1980, on one of the Wednesdays of «Magnēts» in Riga, the number of participants reached even 2400. In 1987, there were even 2484 participants [4]. Representatives of the International Orienteering Federation came to Latvia to get acquainted with the achievements and expressed their appreciation admitting that there has not been such mass participation in orienteering competitions on work day evenings as in Latvia. The world's leading athletes from Scandinavia had also come and rejoiced the achievements of Latvian orienteerists.

\section{Childhood and Youth of A. Lïcis}

A. Lìcis was born in Liepāja city on 16 July 1939. His mother - Frīda Lizete Līce (born Karlsone; 1910-1997) [5] - had a daughter, Valda Bredaus (1929-2015), from her first marriage, who was ten years older than Arno. The head of the family - father Voldemārs Gustavs Līcis (18981985) - was a locksmith, a driver of the locomotive, but in his spare time he practised sport. In 1930, he set a record on the trek of Sports Association «Marss» (15 minutes and 5.9 seconds) in the $15 \mathrm{~km}$ ride that remained unrivalled in the USSR until 1975. Trekking cyclist V. G. Licis participated in competitions in the 1930s [6] and wanted to attend the Summer Olympics in Berlin in 1936, but he had no money for it.

Figure 3. In the second row from left: parents of A. Lìcis - Frīda Lizete and Voldemārs Gustavs Lìcis (the late 1930s) [7].

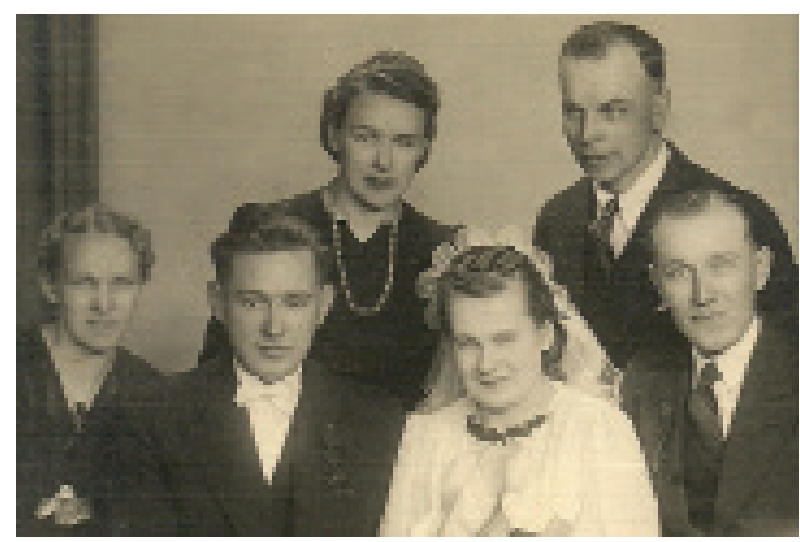


The first years of Arno's childhood took place in Jaunliepäja city. At the age of two, he became ill with asthma in severe form and struggled with the disease until 1954 with varying degrees of success. Because of the disease, he had to study in the 3rd grade for two years. There was no medicine for the disease, therefore folk medicine was used. In 1944, Arno also had diphtheritis. Doctors advised that the family change the place of residence, thus the family moved to «Paisas» (name of the house) at Pērkone parish in Liepāja district and lived there during World War II. A. Licis remembers that he, his sister and mother had done all the farm work for the landlord, but «the most striking impression from the period in «Paisas» has been the one of autumn cereal threshing, when a steam locomotive with a threshing machine went from house to house and our cereal was threshed for two days and in the end all the workers were treated to rich food: the landlord slaughtered a pig, sheep and chicken and brewed beer; and after the evening supper, all workers - about 20 people - sang and danced»[8].

After the war, the family moved to live with their relative and Arno began to learn in 1st grade of Cenkone Four-year School. When he had to change his place of residence again, he studied at the Skatre Seven-year School where, when from the 5th to 7th grade, during physical classes, he became acquainted with sports activities and «was carried away» by football. Arno's father gave him a football and Arno and his schoolmates played for 2-3 hours in a real football field until the head of the school took them home.

At home, Arno had to take on various responsibilities, help the family to keep the livestock and work in the backyard. Thanks to physical activity, asthma was defeated. He often went to school on a bicycle and in winter he skied to school as the distance to school was three kilometres [8].

\section{Studies at the Riga Industrial Polytechnicum}

A. Licis decided to continue his studies at the Riga Industrial Polytechnicum (at present - Riga State Technical School); applied for studies and passed seven entrance examinations in the Faculty of Mechanics. Four groups were enrolled at that time; there were 32 boys in his group. Arno graduated from primary school as an excellent graduate, especially in mathematics and geography, but in the first year of his studies he, in his own words, he merely managed to get through, as in the first session he got low marks (mark «three») in several subjects.

There was a healthy and sporty atmosphere among the students of the Riga Industrial Polytechnicum. In the 1st year of studies, A. Licis was 
the winner of autumn cross running. He was elected organizer of the activities of group's physical culture. The group decided to take part in all sports and all disciplines and four years in a row won the spartakiad of the industrial polytechnicum [8].

A. Licis gradually got used to studies at the Industrial Polytechnicum and life in Riga. Already in the 4th year of studies he was close to being an excellent student. In 1958, after graduation his group was granted a month-long rest camp at the Zvärte Rock. Five young people from Estonia and five from Lithuania participated in the camp.

While studying at the Industrial Polytechnicum, A. Licis besides athletics played also ball games and in the last year he even participated in trainings of the selected team in track and field athletics, volleyball and basketball, as well as took part in the dance group of factory «Riggas audums». In 1958, A. Licis graduated from the Riga Industrial Polytechnicum, obtaining a profession of technician-mechanic (operation and repair of work machines) [8].

\section{Studies of $\boldsymbol{A}$. Lìcis at Riga Polytechnic Institute}

A. Licis begun to work at the Workshop No. 14 of the State Electrotechnical Factory (VEF), which was located in Ganību danbis and produced mobile telephone exchange equipment for the army. Initially, he worked as a locksmith in manufacturing of apparatus, after a year he moved to a newly established group of locksmiths who repaired metal working machines of factory «Komutators». A. Lïcis became a VEF champion in volleyball and football. Due to the back injury during a handball game his recruitment in the Soviet army was postponed for a year. Then the idea of studying at the university was born.

A. Licis left VEF and on 13 May 1960 began to work as a laboratory technician at the Materials Resistance Laboratory of the Faculty of Mechanics of RPI [9]. The then Director of RPI Kristaps Neilands (18991960) called Arno for a meeting. The Director told about himself and asked: «What are your hobbies? Do you drink? Do you smoke?» A. Lìcis replied: «Sport! But when in a company - I am not a total abstainer» [8].

A. Licis enrolled in the evening department of the Faculty of Mechanics of RPI and worked as a lab assistant; he made various laboratory equipment for metal processing machines and participated in preparation of laboratory works for RPI day- and evening department students. The laboratory was located in the basement of the building at 1 Lenina (at present - Kalku) iela. As an employee of RPI, A.Lícis took part in volleyball trainings and sometimes played with the Dean of the Faculty of Mechanics, Assistant Professor Varaidots Zars. When a place of study 
was vacated in the day department, Assistant Professor V. Zars helped Arno move from the evening- to the day department; but there were only studies without practice in the factory. He took the first exam session later, as he had missed many tests and laboratory works and managed to pass satisfactorily. In the spring of 1961, A. Licis was elected person responsible for sports activities in the Faculty of Mechanics [10]. In compulsory physical training he attended athletics with Kärlis Liepinšs (1913-?). But already on 26 March 1961, he participated in friendly competition in orienteering sport between RPI and SUL in Langstini village. He was the 12th in a competition of 80 men. It was an unbelievable result for the first competition and he was «hooked». Arno joined the RPI orienteering group led by Juris Jansons from the Faculty of Civil Engineering [11].

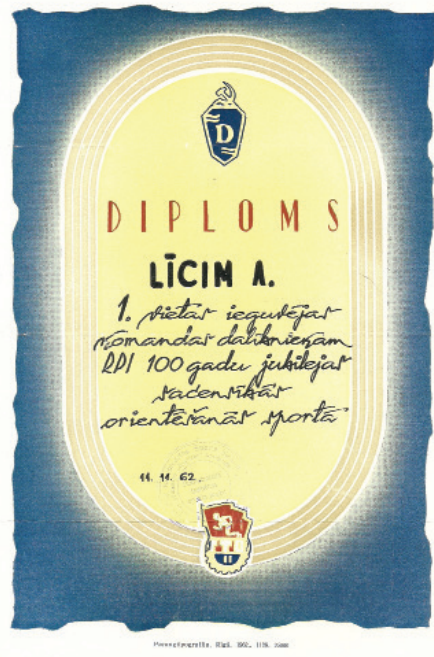

Figure 4. The Diploma of A. Licis for the 1st place of orientation in team at the Orienteering Event dedicated to 100th Anniversary of RPI. 11 November 1962 [12].

The atmosphere in the orienteering environment was very friendly. Joint trainings were attended intensively and attempts were made to participate in all possible competitions in orienteering discipline. Arno experienced the 100th anniversary of RPI - on 11 November 1962, he participated in the competitions dedicated to it [13]. RPI orienteerists were well-known in Latvia for many years, winning awarded places in the Latvian National Team. During studies, A. Līcis won a silver medal at the 1st All-Union Competition in Uzhgorod [14]. Arno's study mates Helmuts Gulevskis, Rodrigo Slavin̄š, Imants Pelns, Māris Blodons, Aivars Teikmanis and others were also active in orienteering.

Only successful students could participate in national teams, A. Lícis was among them. He graduated from the Faculty of Mechanics of RPI on 26 December 1964, obtaining the qualification of an engineer-mechanic in the specialty «Welding Technology and Equipment» [16]. 


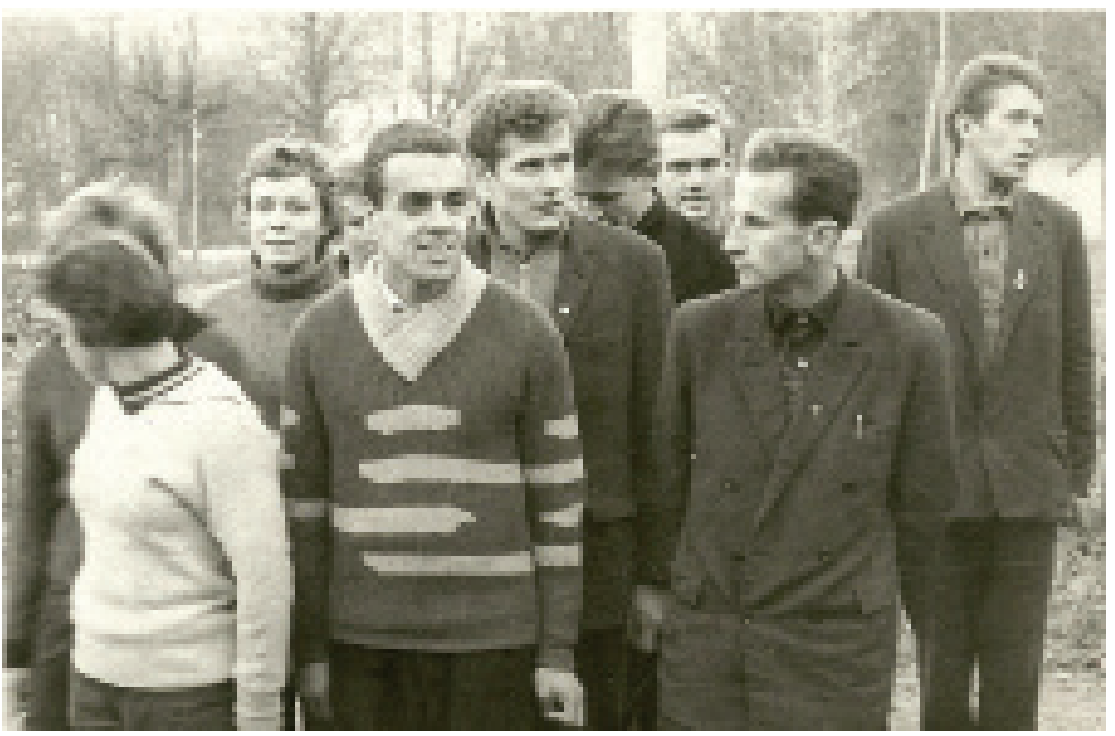

Figure 5. RPI orienteering team in 1962. A. Licis - in the middle of the first row [15].

At that time, all day department students were subjected to an obligatory assignment of young professionals of All-Union. The best graduates could choose the best. Arno was second in terms of success and he chose to work at the Riga Electromachine Building Factory $(R E R)$, where he had already worked for five months in pre-graduate practice.

\section{Work of A. Lïcis at Riga Electromachine Building Factory (RER)}

When choosing a job at RER, A. Licis hoped to learn and use the new possibilities of welding. In 1968, he was promoted to senior engineer. The factory had about 8000 employees at that time. A. Licis implemented inventions and did other works with people of different nationalities who worked very honestly. The number of welders was also high [17]. The factory management appointed him a lecturer of courses for improving the qualification of welders of electric-contacts.

Many processes in the factory were automated but did not always work as intended. And A. Lìcis had a new idea of creating a special facility that would improve the production process. Together with colleagues in the welding laboratory a prototype was first made and the joint effort was successful [8]. In 1970, «top rotary disk electrode point contact welding machine» invented by A. Līcis and his colleagues operated at $R E R$. 


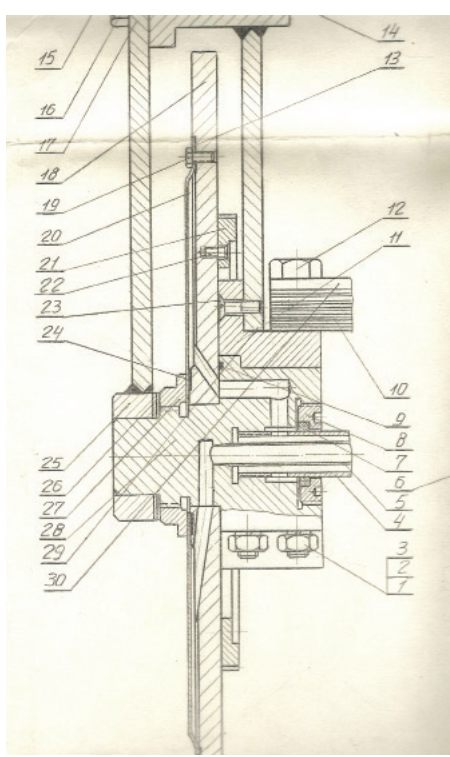

Figure 6. Drawing of invention by A. Lìcis [18].

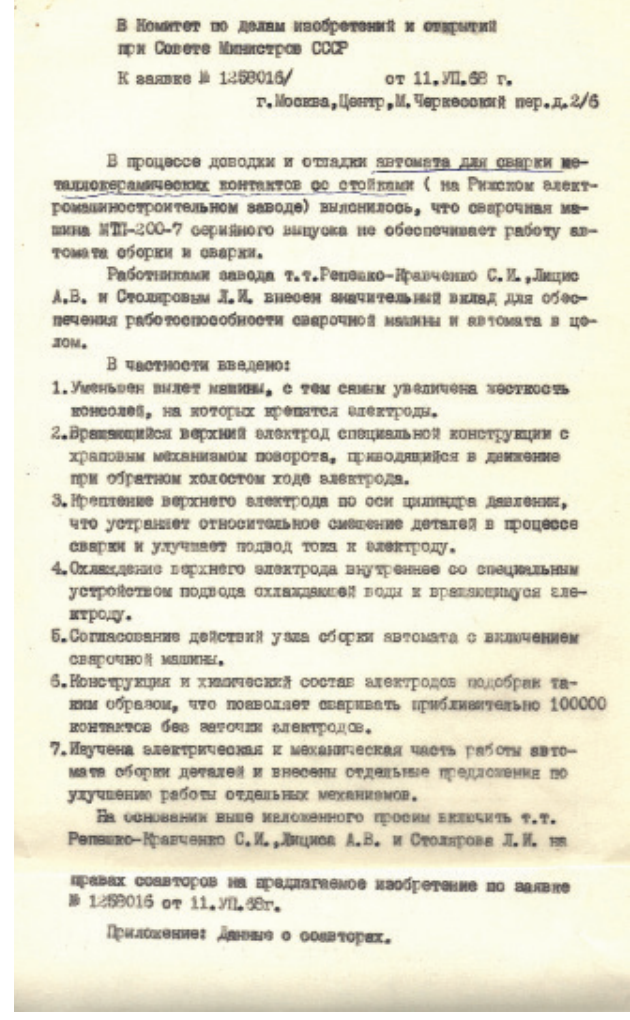

Figure 7. Supplement of the Application to the Committee of Inventions and Discoveries of the Council of Ministers of the USSR (1971) [19].

A. Licis failed to obtain the authorship certificate for various reasons. He was not able to advance his career without joining the Communist Party of the Soviet Union (CPSU), but he did not want to compromise, did not join the party and did not give away his inventions to others.

Engineer A. Licis was sent on a number of business trips with the aim to buy separate contact-machine nodes for $R E R$, such as transformers, etc. and parts. Once there was a special delegation from the USSR Ministry of Electrotechnical Industry which assessed the work done by A. Licis and his colleagues: the number of contact welds (productivity, precision and connection strength) was exceeded several times. Back then, RER was supplied by other ministries and factories with contactors produced in Latvia.

While working as an engineer at RER, Arno trained a team of men and women in orienteering sport and skiing. Participants of the section of 
orienteering sport of factory helped to organize an open competition of the republic - «Solo». The first one took place in 1972 at Lake Usma, with 800 participants. Arno and his future wife Ievina ran competition «Solo» for eight years. In 1975, A. Lìcis left RER.

\section{Work of $A$. Licis at the Latvian Institute of Traumatology and Orthopaedics (LSRITO)}

Unable to see growth opportunities at RER, A. Licis changed his life drastically in 1975 - he joined LSRITO as a medical equipment engineer, where he worked for 20 years.

In 1990, A. Lìcis helped organizing the World Conference of Latvian Doctors (WLD), which took place in Riga and was responsible for sports activities in six sports. The main organizers and authors of the WLD conference were Professor Viktors Kalnbērzs (Director of LSRITO) and Kristaps Keggi (USA) - both of them world-renowned traumatologists orthopaedists.

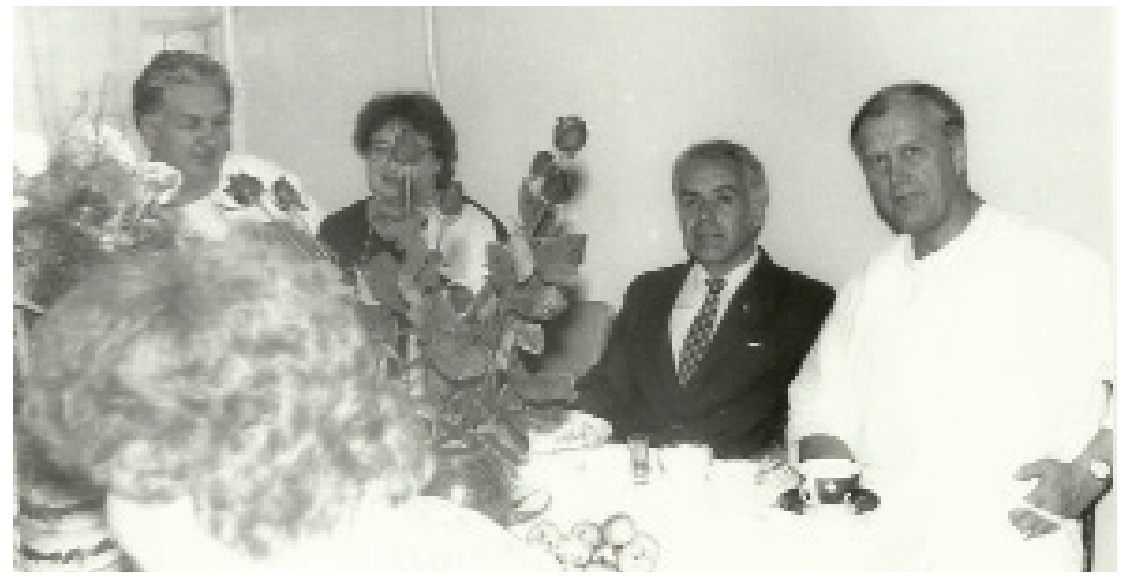

Figure 8. Celebration of the 50th anniversary of A. Licis (second from right) with Professor Viktors Kalnbērzs (first from right) and LSRITO colleagues (1989) [20].

LSRITO was the only medical institution with its photo-cinema laboratory, which documented all complex operations, therefore all AllUnion and International Traumatology Conferences were held in Riga, at the LSRITO Clinic. A. Lìcis as an engineer and technician had to take an active part in transmitting operations' broadcasts from the operating room without interruption to the Assembly Hall, where conference participants were able to observe the progress of operations at close on the screen.
Graduate of

Riga Polytechnic Institute, Engineer, Inventor and Athlete Arno Līcis 
While working in LSRITO, A. Licis became involved in the first orienteering sports club «Kapa» founded in 1987 in Carnikava village. A. Lìcis was elected a board member of the club and participated in many sports events of it. He was the chief judge of the run «Daugava-Gauja» organized by the club for ten years (1987-1996) [8].

During his 20 years of work, A. Licis expanded the activity of LSRITO in the field of medical sports after he was elected a member of Trade Union Committee of institute responsible for the organization of active recreation. Simple sports equipment (skis, sports suits, hockey sticks, etc.) was purchased for the money allocated by the Trade Union of LSRITO. The Institute's doctors played basketball in the TTT Hall. During a friendly hockey match with the doctors from Hospital «Gailezers» in the Sport's Palace, Professor of LSRITO V. Kalnbērzs was the goal-keeper. The hall was full of supporters. In 1990, a hockey team of Canadian doctors arrived on a sports trip to the USSR; they played with a soft outfit, avoiding the open force game to avoid injury. When in Riga, playing with our doctors, the Canadians were warmly welcomed: after the hockey game there was a dinner with music and singing. The guests were so excited that they invited their Riga colleagues - doctors - to visit Canada next year and participate in the Toronto Doctors' Hockey Tournament. A. Licis (the only doctor without qualification) participated in this event in 1991, playing hockey for 12 days in 14 different cities in the provinces of Ontario [21]. LSRITO doctors were also at Niagara.

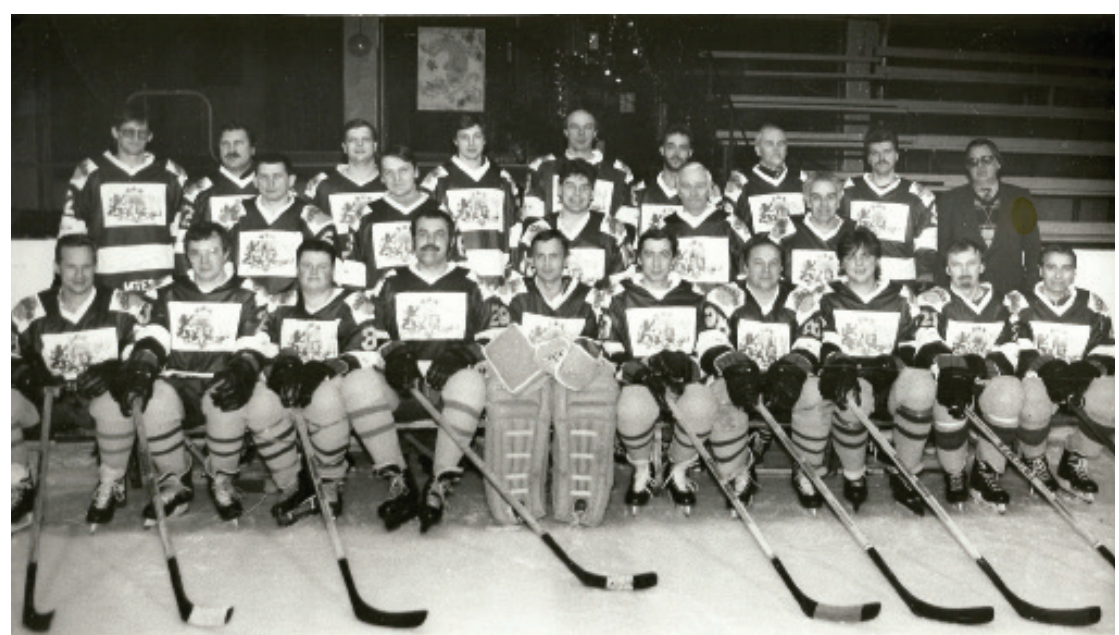

Figure 9. A. Licis (first from right in the second row) in LSRITO doctor's hockey team in Canada (1991) [22]. 
From 1985 until 1995, about 30 medical staff (including heads of departments) took part in orienteering competition «Magnēts»; a 60 kilometres skiing marathon in Tartu, Tartu cycling marathon of $120 \mathrm{~km}$ and many other long skiing distances in Latvia, such as Césis-Ligatne, Marathon of Jauja, etc. When telling the doctors about orienteering competition «Magnēts», A. Lìcis often said that no special equipment is needed, except a compass and a map and the only rule is that you should not run when participating for the first time, the distance should be done carefully, observing nature in the map to better understand the essence of orientation.

After the declaration of independence of Latvia in 1990, the LSRITO sports activities decreased. LSRITO began building a new treatment facility with many operating rooms. A. Licis travelled abroad and met with his foreign counterparts in an effort to set up better equipped operating rooms that are more sterile and comfortable. LSRITO was reorganized into the Hospital of Traumatology and Orthopaedics and engineer A. Licis [23] was appointed Deputy for Economic Affairs of Director of Hospital Valdis Zatlers. A. Licis was the technical supervisor of the construction, installation and purchase of equipment and putting into service of the new hospital building. A. Licis worked in this position for a year and a half when again a new turn in his life came.

In August 1995, the owners of the printing house «Jāna sēta» talked A. Licis into changing his work in medicine for work in printing inviting him to become director of «Rota-1» and «Rota-3». After a long period of consideration and discussions in the family, he decided to take this daring step - to plunge into an unknown and alien field. Immediately in the first month of work (in October), he was tasked with arranging the production of strict records on paper with watermark protection.

In 1996, printing house «Rota-1» was moved to Brīvības iela and joined printing house «Rota-3», who printed and drew books. For various reasons, it was necessary to look for other rooms and the choice fell on Silakrogs.

A. Licis retired after nine years of working in the field of printing.

\section{Practical Works and Family of A. Lïcis}

In 1968, Arno met and became friends with a girl named Ievina. She helped to organize orienteering competition «Magnèts». And they ran this competition for 10 years: Arno - Chief Referee and Ievina - Chief Secretary.

In 1972, they founded a family. In 1974, their daughter Lienite was born. Eight years later, in 1982, their second daughter, Liga was born, 
but in 2003 - their granddaughter Helēna. Along with all the work with the help of Ievina's parents, a family house was built and after the wedding the young couple could settle in one of its rooms. Arno and Ievina had intense trainings as they were participants in Latvian orienteering sport. In addition, Ievina and Arno have been the wedding hosts in seven weddings.

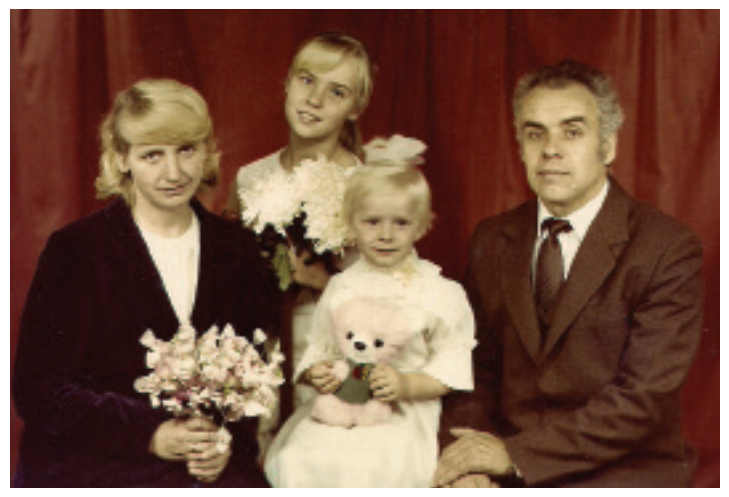

Figure 10. A. Lìcis with his wife Ieving and daughters (in the1980s) [24].

A. Licis' spouse Ievina got infected with the Lyme disease in 1995 after an infected tick bite. Arno was with her for 12 years of illnesses and in 1999, together with a group of friends, even brought her to the top of Mont Blanc.

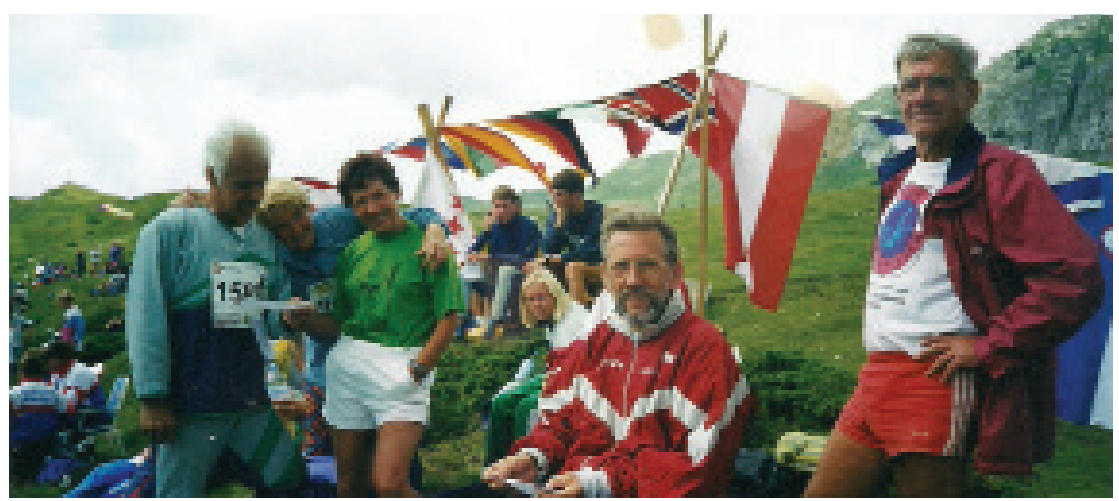

Figure 11. Arno and Ievinga - first from left, R. Slaviņš - second from right, H. Gulevskis (1937-2019) - first from right during a break in orienteering competitions in Switzerland (1999) [25].

Later, after Ievina went passed away in 2007, his sister Valda moved in with him and he took care of her until the end of her life in 2015. It was not easy, but it had to be done. 


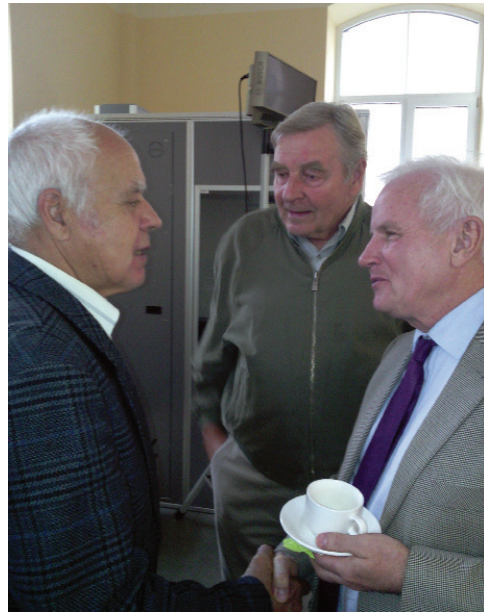

Figure 12. From left: A. Lìcis with RPI lecturer Ainis Kärklinšs and Director of RTU Administrative Department Jans Šlihte on RTU History Day on 10 October 2018 [26].

A. Licis' days of the deserved rest are as busy as those in his working years: games of sport's veterans, gardening, home improvement, book reading, beekeeping, horticulture (everything in the greenhouse grows what is needed), fruit growing.

\section{Conclusions}

There are more than tens of RPI students and graduates who have worked in Latvia and have given invaluable and lasting contribution. Among them is Arno Licis - graduate of RPI, engineer, inventor, orienteering athlete, organizer of sports life, initiator of mass competition «Magnēts», father, husband, gardener, beekeeper, wedding host, nominee of «Latvijas Lepnums» («Latvian Pride»). He was born in an independent state of Latvia and he always expressed a clear position and his conviction. Meanwhile, his intellectual, organizational and communication abilities and competencies were so excellent that in Soviet times, his colleagues, leaders and civil servants appreciated it and offered to try atypical things in his career [8]. His professional activities and sports achievements, human quality and optimism made an invaluable contribution to Latvia - in 2019, his orienteering competition «Magnēts» took place for the 51st time.

In 2006, for his devoted and successful work for the benefit of the Latvian State and the nation, A. Licis was awarded the Certificate of Recognition of the Cabinet of Ministers [27]. Riga Technical University, the successor of RPI tradition and work, can be proud of such graduates. 


\section{CONFLICT OF INTEREST}

The authors of the scientific article acknowledge a conflict of interest related to the joint professional work of the authors and members of the Editorial Board. The inclusion of this article in the issue was decided by those members of the Editorial Board who are not the authors of this article.

\section{LIST OF SOURCES AND LITERATURE}

[1] A. Līcis (20. gadsimta 60. gadu sākums). Foto no A. Līča personīgā fotoarhīva.

[2] PSRS Sporta biedrību un organizāciju savienības Centrālās Padomes Goda raksts A. Līcim (1967). No A. Līča personīgā arhīva.

[3] Paikena, V. «Magnēta» bums. Liesma, 1983. gada 1. septembris, Nr. 9, 6. lpp.

[4] Jaunzemis, J. Magnēts bija un būs. Diena, 1993. gada 6. decembris, Nr. 263, 7. lpp.

[5] Frīdas Lizetes Līces Latvijas Republikas pavalstnieces pase. 20. gadsimta 30. gadi. Latvijas Latvijas Nacionāla arhīva Latvijas Valsts vēstures arhīvs (turpmāk - LNA LVVA) 2996. f., 11 apr., 18994 l., 4. lp.

[6] Latvijas meistarsacīkstes riteņbraukšanā. Stadions, 1933. gada 14. augusts, Nr. 48, 5. lpp.

[7] Arno Līča vecāki - Frīda Lizete un Voldemārs Gustavs Līči (20. gadsimta 30. gadu beigas). Foto no A. Līča personīgā fotoarhīva.

[8] Ērikas Lankas intervija ar Arno Līci 2018. gada 27. septembrī. $\bar{E}$. Lankas personīgais arhīvs.

[9] Laboranta Arno Līča personāllieta. RTU arhīvs.

[10] Arno Līča studenta personāllieta. RTU arhīvs.

[11] Jansons, J. Mūsu tūristi - Vissavienības sacensību uzvarētāji. Jaunais Inženieris, 1962. gada 20. februāris, Nr. 3, 4. lpp.

[12] Diploms A. Līcim par 1.vietu orientēšanās komandā RPI 100 gadu jubilejas sacensībās orientēšanās sportā. 1962. gada 11. novembrī. No Arno Līča personīgā arhīva.

[13] Tuvojas LVU orientēšanās sacensības. Padomju Students, 1962. gada 16. novembris, Nr. 29, 2. lpp.

[14] Pelns, I. Atjautīgo un izturīgo sports. Jaunais Inženieris, 1963. gada 9. decembris, Nr. 19, 4. lpp.

[15] RPI izlase orientēšanās sportā (1962). A. Līcis - 1. rindā vidū. Foto no A. Līča personīgā fotoarhīva.

[16] Arno Līča RPI diploms. 1964.gads. No A. Līča personīgā arhīva.

[17] Ar kompasu un karti. Rezietis, 1974. gada 3. jūnijs, 2. lpp.

[18] Arno Līča izgudrojuma rasējums. No Arno Līča personīgā arhīva.

[19] Pieteikuma papildinājums Izgudrojumu un atklājumu komitejai pie PSRS Ministru Padomes (1971). No A. Lǐča personīgā arhīva. 
[20] Arno Līča (2. no labās) 50 gadu jubilejas svinībās ar profesoru Viktoru Kalnbērzu (pirmais no labās) un LTOZPI kolēǵiem (1989). Foto no A. Līča personīgā fotoarhīva.

[21] Ž̄̄gurs, A. Rīgas ārsti Kanādā. Latvija Amerikā, 1991. gada 20. aprīlis, Nr. 16, 8. lpp.

[22] A. Līcis (pirmais no labās 2. rindā) LTOZPI ārstu izlases hokeja komandā Kanādā (1991). Foto no A. Lìča personīgā fotoarhīva.

[23] Lībrins, A. Vai dolāri paliks Latvijā? Diena, 1991. gada 9. jūlijs, Nr. 128, 2. lpp.

[24] Arno Līcis ar sievu Ievinuu un meitām (20. gadsimta. 80. gadi). Foto no A. Līča personīgā fotoarhīva.

[25] Arno un Ieviṇa Līči (pirmie no kreisās), otrais no labās - R. Slaviṇš, pirmais no labās - H. Guḷevskis (1937-2019) atpūtas brīdī orientēšanās sacensībās Šveicē (1999). Foto no A. Liěca personīgā fotoarhīva.

[26] A. Līcis ar savu RPI mācībspēku Aini Kārklinuu un RTU administratīvo direktoru Janu Šlihti RTU Vēstures dienā 2018. gada 10. oktobrī. Foto no Ērikas Lankas personīgā fotoarhīva.

[27] Karlsons, P. Sports. Laiks, 2006, 10. jūnijs, Nr. 24, 24. lpp.

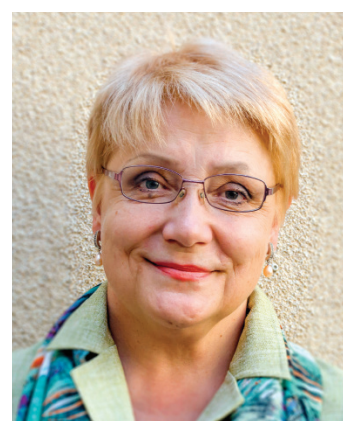

ËRIKA LANKA, Mg. paed., Mg. phil., graduated from University of Latvia. From 1984, she has been a lecturer at University of Latvia, from 2008 to current time she works as Director of one of the Programmes at the Centre of Adult Pedagogical Education at the Faculty of Education, Psychology and Art. She participates as an expert in a lot of Latvian and foreign research projects, at the same time working as a teacher at schools. Her main academic interests include the philosophy of education, ethics, axiology, values and codex of teacher, history of pedagogy in Latvia and in Europe. She is a co-author of two monographies and the author of more than 30 publications.

Address: 1 Imantas 7. linija, Riga, LV1083, Latvia

Phone: +37129264829

E-mail: Erika.Lanka@lu.lv,erikalanka@inbox.lv

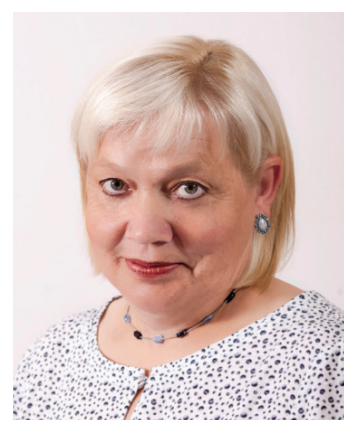

ALİDA ZIGMUNDE, Dr. paed., has been a Specialist at the Museum of Riga Technical University since 1989. From 2007 to 2015, she was a Senior Researcher. She is currently a Professor with the Institute for Humanities and Head of the Department for Historic Research and Scientific Publications of the RTU Research Centre for Engineering History. Her main academic interests include the history of pedagogy in Europe, the history of the institutions of education and history of engineering sciences and universities.

Address: 1 Kronvalda bulvāris, Room 203, Riga, LV-1010, Latvia

Phone: +37129869642

E-mail: alida.zigmunde@rtu.lv 


\section{Rīgas Politehniskā institūta absolvents, inženieris, izgudrotājs un sportists Arno Līcis}

Rakstā apkopots Rīgas Politehniskā institūta (RPI) Mehānikas fakultātes 1964. gada absolventa Arno Līča veikums inženiera profesijā Rīgas elektromašīnbūves rūpnīcā (RER), Latvijas Traumatologiijas un ortopēdijas zinātniskās pētniecības institūtā (LTOZPI) un tipogrāfijā «Jāṇa sēta», kā arī raksturota viṇa izgudrotājdarbība, atklāti nopelni orientēšanās sporta popularizēšanā un sasniegumi dažāda mēroga sacensībās, tostarp viṇa izveidotajās masu sacensībās «Magnēts», kas notiek kopš 1969. gada. Šis ir pirmais pētījums par inženiera A. Līča darbību un dzīvi, kas tapis, sagaidot viña 80. dzimšanas dienu 2019. gada jūlijā. Tajā izmantots A. Līča personīgais arhīvs, Latvijas Valsts arhīva dokumenti un Latvijas Nacionālās bibliotēkas krājums.

Atslēgas vārdi: Arno Līcis, RPI absolventi, orientēšanās sports, «Magnēts».

Эрика Ланка, Алида Зигмунде

\section{Выпускник Рижского политехнического института, инженер, изобретатель и спортсмен Арно Лицис}

В статье обобщен вклад выпускника Механического факультета Рижского политехнического института (РПИ) 1964 года Арно Лициса в профессию инженера на Рижском электромашиностроительном заводе (РЭЗ), в Латвийском институте травматологии и ортопедии (ЛИТО), типографии «Jāna sēta», а также охарактеризована его изобретательская деятельность, выявлены заслуги в популяризации спортивного ориентирования и достижения в различного рода соревнованиях, в том числе в организованных им массовых соревнованиях «Magnēts», которые проводятся с 1969 года. Это первое исследование деятельности и жизни инженера А. Лициса, которое проводится в преддверии его 80-летия в июле 2019 года. В нем использован личный архив А. Лициса, документы Государственного архива Латвии и собрание Латвийской Национальной библиотеки.

Ключевые слова: Арно Лицис, выпускники РПИ, спортивное ориентирование, «Magnēts». 